\title{
De kern van de zaak. Over zes grondslagen van de interne geneeskunde
}

Citation for published version (APA):

Stehouwer, C. D. A. (2005). De kern van de zaak. Over zes grondslagen van de interne geneeskunde. UM. https://doi.org/10.26481/spe.20051007cs

Document status and date:

Published: 07/10/2005

DOI:

$10.26481 /$ spe.20051007cs

Document Version:

Publisher's PDF, also known as Version of record

\section{Please check the document version of this publication:}

- A submitted manuscript is the version of the article upon submission and before peer-review. There can be important differences between the submitted version and the official published version of record.

People interested in the research are advised to contact the author for the final version of the publication, or visit the DOI to the publisher's website.

- The final author version and the galley proof are versions of the publication after peer review.

- The final published version features the final layout of the paper including the volume, issue and page numbers.

Link to publication

\footnotetext{
General rights rights.

- You may freely distribute the URL identifying the publication in the public portal. please follow below link for the End User Agreement:

www.umlib.nl/taverne-license

Take down policy

If you believe that this document breaches copyright please contact us at:

repository@maastrichtuniversity.nl

providing details and we will investigate your claim.
}

Copyright and moral rights for the publications made accessible in the public portal are retained by the authors and/or other copyright owners and it is a condition of accessing publications that users recognise and abide by the legal requirements associated with these

- Users may download and print one copy of any publication from the public portal for the purpose of private study or research.

- You may not further distribute the material or use it for any profit-making activity or commercial gain

If the publication is distributed under the terms of Article $25 \mathrm{fa}$ of the Dutch Copyright Act, indicated by the "Taverne" license above, 


\section{De kern van de zaak}

Over zes grondslagen wan de interne geneeskunde 


\section{Colofon}

Basicontwerp en realisatie: Unigraphic, Lniversiteit Mastricht.

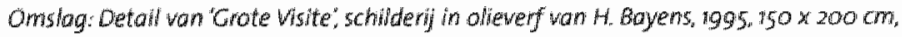
gevchilderd in opdwacht wan de vereniging Nederlonds Tijdschrift woor Geneestunde.

bur Hayens, Crote Visite (detaill, c/o Beeldrecht Amsterdam zoos.

Ahe rechtem wootbehouden. Niets uit deze uitgawe mag worden verveewoudigd, opgeslagen in en geou tomatiseerd gegevens bestond of operboar gemaokt, zonder woorafgaonde schrifte. ligke toestemming van de autew of uitgewer. 


\section{De kern van de zaak}

Over zes grondslagen van de interne geneeskunde

\section{Rede}

uitgesproken bij de aanvaarding van het ambt van hoogleraar in de interne geneeskunde aan de Universiteit Maastricht

op vrijdag 7 oktober 2005

door

prof. dr. C.D.A. Stehouwer 

Mijnheer de Rector Magnificus,

Zeer geachte toehoorders,

Interne geneeskunde houdt zich bezig met zlekten van de inwendige organen uitgezonderd primaire aandoeningen van de vrouwelijke geslachtsorganen en de hersenen. Dat klinkt als een breed gebied en dat is het ook. Daardoor is veel van wat ik in deze rede aan de orde zal stellen niet alleen relevant voor de interne geneeskunde, maar ook voor de geneeskunde in het algemeen.

Ik meem u mee naar een kernactiviteit van ledere afdeling interne geneeskunde: het ochtendrapport. We bespreken daar de patiënten die in de 24 uur daarvoor zijn opgenomen. De arts in opleiding tot internist rapporteert. Zij heeft's nachts een 78 -jarige voormalige tuinman opgenomen met een maagbloeding. Hij gebruikte zogenoemde niet-steroidale ontstekingsremmers vanwege gewrichtspijn. Een maagdarmlever-arts merkt op dat zulke pijnstillers vaak maagzweren veroorzaken, en soms maagbloedingen. Een internist merkt op dat richtlijnen aanbevelen dat aan oudere mensen aan wie zulke pijnstillers worden voorgeschreven, tevens maagzuurremmers moeten worden geadviseerd, omdat die de kans op maagzweren verminderen. Dat was bij deze patiént niet gebeurd. Nu werd behandeling gestart met een zuurremmer. De arts in opleiding tot internist gaat verder met een andere patiënte, een 40 jarige huisvrouw met hoge koorts, hoestklachten en kortademigheid. Ze vermoedt een longontsteking. Ze heeft onderzoek afgesproken om de verwekker van de longontsteking te achterhalen en heeft intussen behandeling met antibiotica gestart.

Het doel wan zo'n ochtendrapport is tweeledig. Ten eerste is het een dienstoverdracht. We werken tegenwoordig in een drieploegendienst, en 's morgens draagt de nachtploeg over aan de dagploeg. Het tweede doel is continue scholing door patiëntgebonden toetsing en terugkoppeling. Daarom zijn bij het ochtendrapport internisten van allerlel pluimage aanwezig - algemeen internisten, ouderengeneeskundigen, hematologen, oncologen, vasculair geneeskundigen, endocrinologen, nefrologen, infectiologen en immunologen - en daarnaast reumatologen en maagdarmlever-artsen. Die rijkdom aan expertise is nodig voor een kwalitatief goed ochtendrapport en dus voor goede patiëntenzorg en opleiding. Het ochtendrapport eindigt met een zogenoemde zoekvraag, dat is een korte kritische bespreking van wat de wetenschappelike literatuur zegt over 
een specifiek probleem. Heeft bepaling van het urine-amylase nut bij vermoeden van alvleesklierontsteking? Wanneer is stolseloplossende behandeling nodig bij een longembolie, dat is een bloedstolsel in de longen?

\section{De eerste grondslag van de interne geneeskunde: wan klacht naar diagnose en behaindeling}

De eerste kern van de interne geneeskunde is niet moeilijk te vinden. De curatieve interne geneeskunde begint met een patient die een hinderlijke klacht heeft. De internist tracht een diagnose te stellen en geeft daarna een therapeutisch advies. Bij de preventieve interne geneeskunde gaat het, analoog, om het schatten van het risico op een ziekte, respectievelijk het geven van adviezen om dat risico te verkleinen.

\section{De tweede grondslag van de interne geneeskunde: de variatie tussen individuen}

De tweede kern van de interne geneeskunde, in feite een kernprobleem, is óok niet moeilijk aan te wijzen. Het is de variatie tussen individuen. In het klachtenpatroon, in de ziekteverschijnselen, in de uitslagen bij diagnostische tests, in het beloop van de ziekte zonder behandeling, en in de respons op behandeling. Een fietsenmaker ziet meestal snel wat er mis is met een kapotte fiets: de diagnostiek van kapotte fietsen is niet ingewikkeld. De fietsenmaker hoeft ook geen gerandomiseerd en gecontroleerd onderzoek te doen bij een grote groep fietsen om te weten hoe hij een fiets effectief moet repareren. Fietsen zitten niet zo ingewikkeld in elkaar. Bij mensen ligt het anders. Diagnostiek varieert van heel eenvoudig tot zeer ingewikkeld. Bij de interne geneeskunde is diagnostiek meestal niet simpel, noch de beoordeling van de walarde van diagnostische tests. Behandelingen zijn een enkele keer zó spectaculair effectief dat geen ingewikkeld onderzoek naar effectiviteit nodig is: het $k$ lassieke voorbeeld is het effect van penicilline bij longontsteking. Maar meestal is het ingewikkelder.

De derde grondslag van de interne geneeskunde: hoe komt men voor de individuele patiênt tot de juiste dlagnose en behandeling? Het verhaal van de patiënt en het lichamelijk anderzoek

De belangrilkste diagnostische instrumenten van de internist zijn het verhaal vàn de patiênt (de anamnese) en het lichamelijk onderzoek. Van deze twee is de anamnese het belangrijkst. Lichamelijk onderzoek is wooral informatief indien er onmiskenbare afwijkingen zijn. De betrouw- 
baarheid van lichamelijk onderzoek bij minder evidente afwijkingen laat helaas veel te wensen over. Die betrouwbaarheid kan overigens, voor de interne geneeskunde, verbeterd worden door het zelf uitwoeren van eenvoudig echografisch onderzoek. Wij doen dat bijvoorbeeld voor het vaststellen van de vulling van de urineblaas en van de breedte van de holle ader, een maat voor de aanvoer van bloed aan het hart. Wij zouden echografie ook kunnen gebruiken voor het vaststellen van de grootte van lever en milt, en van de aanwezigheid van vrij vocht in de buik (ascites). en dat zou in onderwijs en opleiding moeten worden ingewoerd.

De eerste beginselen van anamnese en lichamelijk onderzoek leert men door probleemgeorienteerd onderwijs in de ziektekunde. Dat is nodig, maar niet voldoende, omdat het ons informeert over de gemiddelde patiënt. En die bestaat niet. Sterker: ziekten bestaan niet - alleen zieken [1]. In 1982 werd bij de bekende evolutiebioloog Stephen Jay Gould de diagnose buikvlieskariker gesteld. In handboeken las hij dat de gemiddelde overleving zes maanden was. In 1992 (!) schreef hij daarover een boekhoofdstuk met als titel: the median is not the message. Expertise in anamnese en lichamelijk onderzoek wordt bepaald door het samenspel van kennis en ervaring. Hoe meer patienten men ziet, des te meer expertise men opbouwt, des te meer gevoel men krijgt woor de wariatie in ziekteverschijnselen tussen individuen, en des te beter men wordt in patroonherkenning.

\section{Klinisch redeneren, evidence-based medicine en pathobiologie}

Daarna moet een plan gemaakt worden voor verdere diagnostiek en behandeling. Hoe doet de internist dat? Ze gebruikt klinische redenaties gebaseerd op kennis uit de zogenoemde evidence-based medicine en de pathobiologie. Pathobiologie houdt zich wooral bezig met de vraag hoe iets werkt. Evidence-based medicine houdt zich vooral bezig met de vraag of lets werkt, en zo ja, hoeveel. Een van de belangrijkste instrumenten van de evidence-based medicine is het zogenoemde gerandomiseerde en gecontroleerde klinische onderzoek. Heel kort gezegd gaat dat alswolgt: een groep patiënten krijgt door loting behandeling $A$ of behandeling $B$ (dat kan ook zijn: geen behandeling of een nepbehandeling). Na enige tijd wordt vastgesteld in welke van beide groepen de uitkomsten gemiddeld het beste zijn.

Velen menen ten onrechte dat evidence-based medicine als methode min of meer 'klaar' is. Niets is minder waar. Ten eerste heeft evidence- 
based medicine belangrijke grenzen. Om de beste combinatie van viff matig effectieve behandelingen bij een chronische ziekte te vinden - een situatie die zich in de interne geneeskunde frequent voordoet zijn 31 onderzoeken nodig met 186000 patiênten gedurende 155 jaar [2]. Als men zich daar niet bij neer wil leggen, dan zullen pathobiologische inzichten ons verder moeten helpen. Het tweede probleern is de variatie tussen individuen. Anders gezegd: zijn de resultaten wit wetenschappellik onderzoek toepasbaar op de patient in de spreekkamer? Ook daar heeft evidence-based medicine enorme beperkingen. Richtlijnen ontbreken en empirisch onderzoek naar deze vraag is zeer beperkt [3].

Waar gaat het om? De patiênten die meedoen aan wetenschappelijk onderzoek zljn waak wezenlijk anders dan de patiënten in de spreekka. mer. Die selectie kan enorm zijn - zie figuur 1 .

Dat zou niet erg zijn als we zouden begrijpen wat het effect is wan die selectle op de uitkomsten wan het onderzoek. Daar is echter maar heel weinig over bekend, op wat algemeenheden na. Zo zijn patienten die meedoen aan wetenschappelijk onderzoek vaak gezonder dan patiënten die niet meedoen. Enerzijds betekent dat dat het netto effect (de zogenoernde absolute risicoreductie) in de praktijk groter kan zijn dan in de trial. Anderzijds wordem daardoor de bijwerkingen van geneesmiddelen onderschat. Niet-steroidale ontstekingsremmers worden getest bij patiënten zonder buikklachten of hoge bloeddruk, maar worden veelal als pijnstilier voorgeschreven aan oudere mensen, van wie tenminste de helft buikklachten of een hoge bloeddruk heeft. Bloedingen, de gevreesde bijwerking van bloedverdunners zoals cumarinederivaten, komen in de praktijk óók vaker voor dan in trials [3]. Zulk soort selectie moet men dus trachten te verminderen. Toch zal het principieel onmogelijk zijn alle soorten interventies te testen bij alle soorten patiënten. Daarom is inzicht in de pathoblologie nodig om te beoordelen of de uitkomsten van onderzoek redelijkerwijs toepasbaar zijn op de patiënt in de spreekkamer.

Zulk inzicht is ook nodig om de waarde te beoordelen van zogenoemde subgroepanalysen. Werkt de interventie bij mannen én vrouwen? Bij ouderen én jongeren? Vroeg én laat na het ontstaan van de ziekte die behandeld wordt? Bj patiënten met én zonder andere ziekten? Een subgroepanalyse die latat zien dat een interventie niet werkt bij patiënten met het sterrenbeeld Vissen maar wel bij alle anderen moet men nege- 
Figuur 4. Het effect van selectile op de fractie patienten uit de bevolking die meedoet aan een triali in de tweede lijn

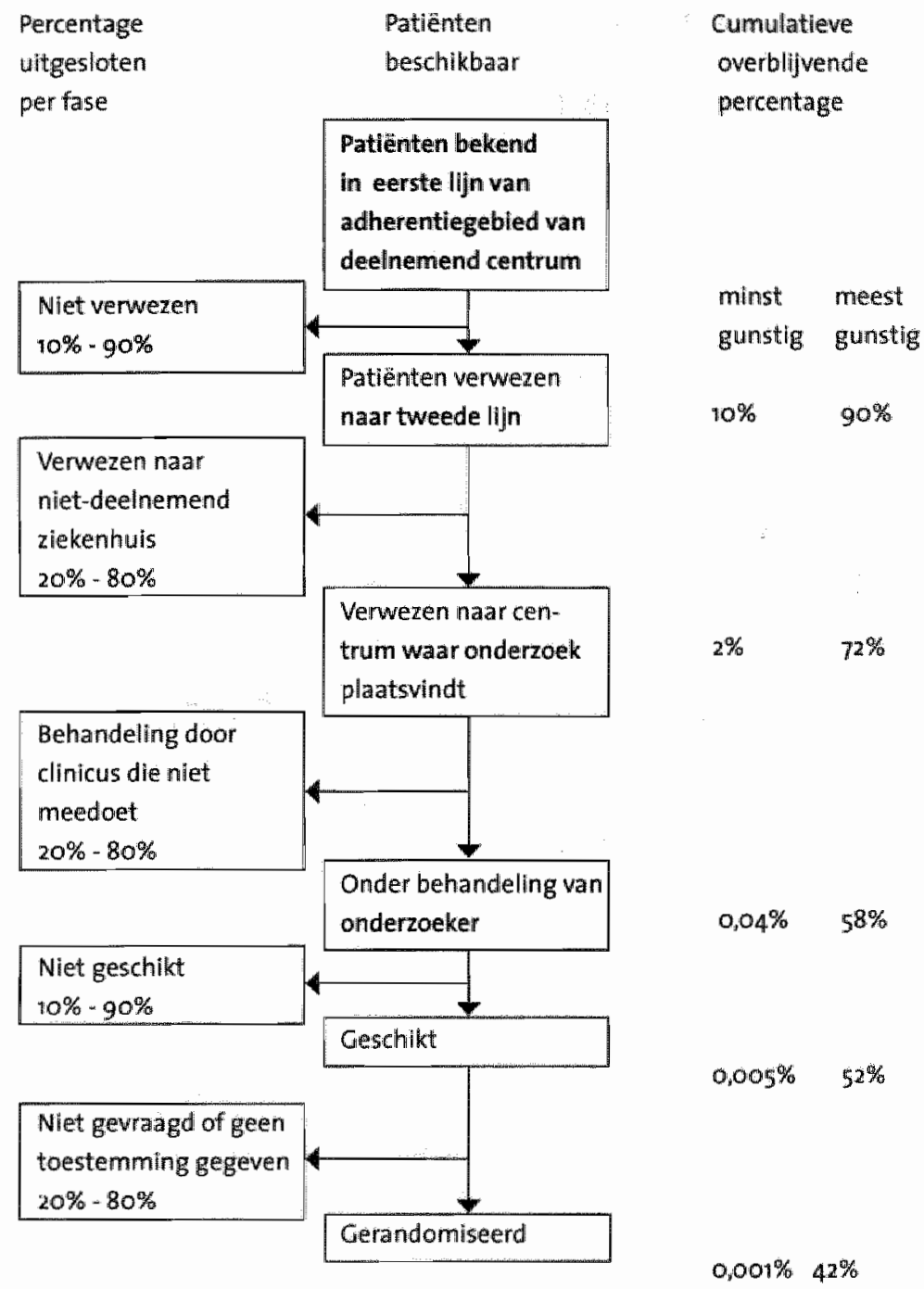

Natr: Rothwell PM. Treating individuals 1 . External validity of randomised controlled trials: "Tow whom do the results of this trial apply?". Lancet $2005,365: 82-93$. 
ren - want de pathobiologische basis ontbreekt. Tabel 1 toont daarentegen een woorbeeld van een klinische belangrijke subgroepanalyse.

Tabel it Rellatief risico ('hazard ratio') op beroerte naar ernst van arteriacarotisstenose en bloeddruk

\section{Systolische bloeddruk ( $\mathrm{mmHg}$ )}

\begin{tabular}{|c|c|c|c|c|}
\hline Stenosegroep & $<30$ & 50-149 & $150-169$ & $>170$ \\
\hline Bilateraal $<70 \%$ & 1 & $q$ & 1 & 1 \\
\hline Unilateral $\geq 70 \%$ & $1,90(1,94-2,89)$ & $1,18(0,92-1,51)$ & $1,27(0,99-1,64)$ & $1,64(1,15-2,33)$ \\
\hline & $p=0,02$ & $p=0,30$ & $P=0,13$ & $p=0,03$ \\
\hline Bilateraal $\approx 70 \%$ & $5,97(2,43-14,68)$ & $2,54(1,47-4,39)$ & $0,97(0,4-2,35)$ & $1,13(0,50-2,54)$ \\
\hline & $\mathrm{P}=0,0001$ & $p=0,001$ & $p=0,95$ & $p=0,77$ \\
\hline
\end{tabular}

De relatieve risico's werden berekend volgens een Cox' regressiemodel, rekening houdend met leeftijd, geslacht en voorafgaande coronaire hart. ziekten. Een risico van 1 wordt toegekend aan patiënten met een bilaterale stenose $<70 \%$. Een stemose van $\geq 70 \%$ houdt alléen dan verband met een werhoogd risico op beroerte bij een relatief lage bloeddruk.

Naar: Rothwell PM. Treating individuals 2. 5 subgroup analysis in randomised controlled trials: importance, indications, and interpretation. Lancet 2005:365:176-86.

Bij patiênten met ernstige vernauwingen van de halsslagaderen blijkt het risico op beroerte vergroot, maar alléén bij een relatief lage bloeddruk ( $<150 \mathrm{mmHg}$ woor dubbelzijdige en $<130 \mathrm{mmHg}$ voor een enkelzijdige vernauwingy. Bij patiènten bij wie de vernauwing operatief was verholpen was dit verband er niet. Dit is klinisch zeer belangrijk. omdat de vuistregel is dat een lagere bloeddruk gemiddeld altijd beter is. Patienten met ernstige halsslagadervernauwingen zijn een uitzon dering op deze regel. Dat is pathobiologisch plausibel omdat bij zulke verna uwingen de druk woldoende hoog moet zijn om de bloeddoorstroming naar het hoofd te waarborgen. 
Kortom: soms zijn subgroepanalysen nuttig: in de spreekkamer zit echter geen subgroep maar een Individu. En de uitkomst voor het individu, dáar gaat het om. Onderstaand schema toont dat voor de behandeling of de preventie van een willekeurige ziekte. Voor preventie kan men lezen: risico op ziekte respectievelijk preventieve maatregel.

\begin{tabular}{|c|c|c|c|}
\hline \multirow{6}{*}{ Zlekte } & Uhtkomst mét & Uitkonst zónder & Behondeling \\
\hline & behandeling & behoundeling & zinwol? \\
\hline & slecht & slecht & nee \\
\hline & goed & goed & nee \\
\hline & goed & slecht & ja \\
\hline & slecht & goed & nee \\
\hline
\end{tabular}

De laatste regel uit dit schema lijkt op het eerste gezicht verrassend, maar soms kan een behandeling inderdaad juist de uitkomst opleveren die men trachtte te voorkomen, zoals bij operaties die bedoeld zijn overlijden te woorkomen. En medicamenteus voorbeeld is het advies aan patienten met een beroerte, aspirine te gebruiken ter preventie van recidieven. Aspirine kan namelijk ook beroerten veroorzaken, al is de netto balans gemiddeld positief: aspirine voorkomt meer beroerten dan het veroorzaakt. Maar de patiënt uit de laatste regel van het schema heeft daar weinig aan. Interventies hebben soms ook bijwerkingen die anders zijn dan de uitkomst die men tracht te voorkomen. We kunnen dat in het schema opnemen.

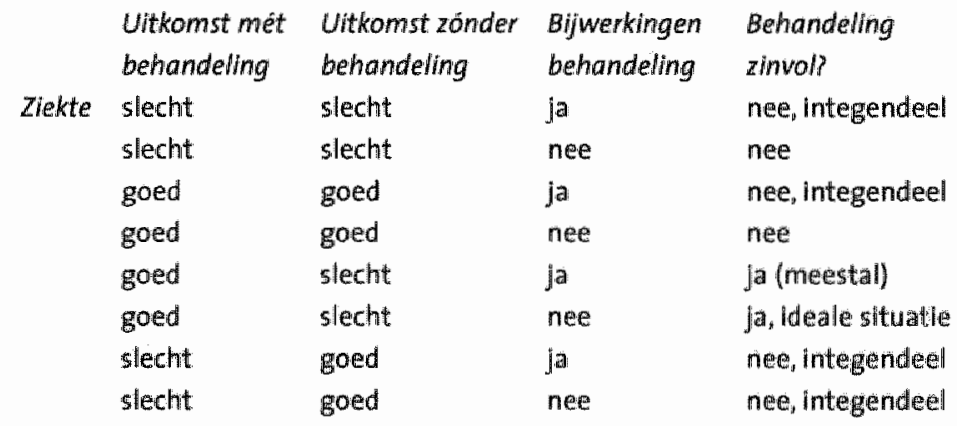

Om de patiènt in de spreekkamer goed te kunmen adviseren moeten wij al deze uitkomsten kunnen voorspellen. Het is zeer de vraag of subgroepanalysen en zogenoemde risicofuncties ons hier voldoende kunnen helpen [3]. Opnieuw is beter inzicht in de pathobiologie nodig. 
Het is dus aannemelijk dat het goed combineren van inzichten uit evidence-based medicine en pathobiologie resulteert in de beste diagnostiek en behandeling voor de individuele patient. Hoe organiseren we dat?

\section{De vierde grondslag van de interne geneeskunde: de organisatie van patiëntenzorg, opleiding en nascholing}

De selectie van de beste diagnostiek [4] en behandeling is ingewikkeld. Daarom is voortdurende, praktijkgebonden methodologische scholing nodig om evidence-based medicine en pathobiolagie op de juiste wijze toe te passen. Dat geldt niet alleen voor artsen in opleiding tot internist, dat geldt zeker áók voor intermisten.

Dat alles heeft gevolgen woor hoe men een academische afdeling interne geneeskunde moet organiseren. Geneeskundestudenten en artsen in opleiding tot internist dienen veel patiënten te zien, deels zelf en deels door patiëntendemonstraties. Bij zulke demonstraties moet de patiënt zoveel mogelijk zélf aanwezig zijn. Er is geen betere manier om gevoel te krijgen voor de variatie in het verhaal van de patiënt dan het van de patiént zélf horen van dat verhaal. Er moet bovendien effectieve terugkoppeling ziln. Dalarwoor is het nodig dat ervaren experts aanwezig zijn, als rolmodel en als gever van feedback. Essentieel is dat experts ook elkaar voortdurend bij- en nascholen, enerzijds omdat dle subdisciplines binnen de interne geneeskunde niet scherp afgrensbaar zijn, en anderzijds omdat de bevolking veroudert - $40 \%$ van de patiënten opgenomen in een ziekenhuils is ouder dan 65 Jar - en omdat oudere patiënten vaak verscheidene aandoeningen tegelijk hebben. Enigszins gechargeerd zijn er twee contrasterende modellen. In het ene staat de ziekte centraal, vaak onder behandeling van een subspecialist die weinig andere taken heeft. Het gevalir daarvan is vertechnisering, fragmentatie, toename van kosten en veromachtzaming van aandoeningen waarin de subspeciallist geen expert is [5]. Bi] een patiènt met meer dan één interne aandoening worden dan verscheidene subspecialisten betrokken, met als nadeel verdunning van de verantwoordelijkheid en onduidelijkheid voor de patiënt. In het andere model staat de patiënt centraal. Indlien enigszins mogelijk behandelt één internist alle intern-geneeskundige aandoeningen die de patient heeft, eventueel na consultatie van subspeciallisten. Daartoe dient men te beschikken over internisten die volledig internist zijn met extra kenn is op een deelgebied, en dient men zulke 
internisten dus ook op te leiden. Het voornaamste bezwaar dat tegen dit model wordt aangevoerd, is dat de geleverde zorg niet optimaal zou zijn, omdat het onmogelijk is alles te weten. Het is waar dat het onmogelijk is alles wit het hoofd te weten. Maar het is wel degelijk mogelijk een breed georiënteerd internist te worden en te blijven indien men om weet te gaan met electronische gegevensbestanden, een goed zicht heeft op de eigen grenzen, en een goed netwerk heeft van te consulteren deelspecialisten. Dat alles wordt beworderd door een goed geintegreerde afdeling interne geneeskunde. Goed omgaan met electronische gegevensbestanden blijkt overigens een kunst die men moet leren, bijvoorbeeld van een clinical librarian. Die dient derhalve in opleidingsziekenhuizen ter beschikking te staan.

Er is nog weinig onderzoek gedaan maar de vraag welk model het beste is. Het lijkt mij aannemelijk dat voor sommige patiënten het ziektegeoriënteerde model beter is, maar voor de meesten het patientgeoriënteerde. Het patiëntgeoriënteerde model heeft daarnaast zeker voordelen voor onderwijs, opleiding en onderzoek binnen de interne geneeskunde, en dient daarom uitgangspunt te zijn. Hoe zou men anders op het idee komen imatinib (een middel dat wordt gebruikt bij chronische myeloide leukemie, een vorm van bloedkanker) te testen bij ongevoeligheid voor insuline, zoals men ziet bij diabetes?

Het instandhouden van een groep breed georiënteerde internistenmet-een-extra-expertise vergt een veelheid aan gemeenschappelijke besprekingen en activiteiten, en nauwe samenwerking tussen deelgebieden binnen één afdeling. De experts (de stafleden) moeten dus de tijd krijgen te scholen en geschoold te worden.

Daaruit volgen twee strenge adviezen aan mensen die de wereld willen verbeteren. Ten eerste: wie het curriculum van geneeskundestudenter en van artsen in opleiding tot internist wil veranderen, moet zich realiseren dat de hoeveelheid contact met patiënten bepaalt wie een goede arts of specialist wordt. Portfolio's, cursorisch onderwijs en reflectiedagen zijn goed, maar patiënten zien is beter. Ten tweecle: wie de organisatie van een samenhangende groep klinische disciplines zoals de interne geneeskunde wil veranderen, moet zich realiseren dat die samenhang nodig is voor goedle patiëntenzorg, voor goed wetenschappelijk onderzoek en voor goede scholing van geneeskundestudenten en van artsen in opleiding tot internist. 


\section{De viffde grondslag van de interne geneeskunde: opvattingen over oorzaken van ziekten [6]}

Opvattingen over oorzaken van ziekten zijn de grondslag van evidence-based medicine én pathobiologie. Daar wordt weinig aandacht aan besteed - helaas, want bij het redeneren over oorzaken wan zlekten worden iedere dag veel fouten gemaakt. Die onzorgvuldigheid bij het denken over oorzakelijkheid wordt goed zichtbaar bij kwesties zoals die van het chronische-vermoeld heidssyndroom - is het een ziekte? Wat zijn de oorzaken? Maar ook bij gewone, 'gevestigde' aandoeningen blijken onze opvattingen over zlekteoorzaken belangrijk. Een recente discussie over urineweginfecties [7] illustreert dat. Daaruit blijkt namelijk dat het niet duidelijk is hoe urineweginfecties moeten worden gedefinieerd doordat onzekerheid bestaat over de oorzaken ervan. Vervolgens blijkt dat de 'beste' strategie woor diagnostiek en behandeling van urineweg. infecties afhangt wan de definitie die men prefereert, dus van de opvatting die men heeft over oorzaken wan urineweginfecties.

Kortom: achter opvattingen over diagnostische tests en behandelstrategieen gaan opvattingen over oorzaken van ziekte schuil. $\mathrm{En}$ : het identificeren van oorzaken van ziekten blijkt opmerkelijk moeilijk. Om het denken over oorzaken wan ziekten te verbeteren, doe $i k$ vier aanbevelingen.

\section{Aanbeveling 1: denk niet: 'ledere ziekte heeft één hoofdoorzaak', maar gebruik de concepten 'deeloorzaken en oorzakelijk complement"}

De epidemioloog Kenneth Rothman heeft in 1976 over het denken over oorzaken van ziekten een klassiek artikel geschreven [8]. Zijn denkmodell over oorzakelijkheid is toepasbaar op alle denken over aorzaak en gevolg; of dat nu epidemiologisch, klinisch of pathobiologisch georienteerd is.

Een oorzaak van een ziekte is een gebeurtenis, toestand of eigenschap die voorafgat aan de ziekte en waarzonder de ziekte niet of pas later zou zijn ontstaan. Deze definitie brengt vier concepten met zich mee. In de geneeskunde gaat het altijd om deeloorzaken. Diabetes kan leiden tot nierfalen, maar dit komit uiteindelijk bij minder dan $50 \%$ van de diabetespatiënten voor, zodat kennelijk andere deeloorzaken aanwezig moeten zijn voordat diabetes leidt tot mierfalen. Roken kan leiden tot longkanker, maar de meeste mensen die roken krijgen geen long- 
kanker. Een voldoende oorzaok is een set deeloorzaken die, indien aanwezig, onvermijdelijk tot de ziekte leidt. Een noodzakelijke oorzaak is een deeloorzaak waarzonder een ziekte niet ontstaat [9]. Studenten geneeskunde leren dat roken, een hoge cholesterolconcentratie in bloedplasma, hoge bloeddruk en diabetes mellitus corzaken zijn van een hartinfarct. Dat is niet juist: het zijn deeloorzaken. Zelfs in combinatie zijn deze factoren overigens geen noodzakelijke deeloorzaak, want hartinfarcten komen ook voor bij patiënten bij wie al deze factoren afwezig zijn, noch een valdoende oorzaak, want hartinfarcten komen soms niet voor bij patiënten bij wie al deze factoren wél aanwezig zijn. Het oorzakelijke complement van een deeloorzaak $D$ is de verzameling andere deeloorzaken die samen met $D$ een voldoende oorzaak van een ziekte vormt. Als wij geïnteresseerd zijn in oorzaken van longtuberculose en als besmetting met de tuberkelbacil $D$ is, dan is het oorzakelijke complement de set overige factoren die bepaalt of de patient longtuberculose krijgt, zoals de voedingstoestand en de effectiviteit van het afweersysteem. Een ander fraai voorbeeld van het belang van het oorzakelijke complement is dat van twee zusters met een identieke erfelijke afwijking, namelijk autosomaal dominante retinitis pigmentosa, een ziekte van het netvlies. De ene was blind, de andere een vrachtwagenchauffeur die ook 's nachts haar weg goed wist te vinden [10].

Is dat alles nu praktisch van belang? Jazeker. Wie het concept deeloorzaak gebrulkt, zal niet de fout maken nieuw ontdekte 'oorzaken' wan een ziekte alleen op te sporen bij patienten bij wie de 'bekende' oorzaken afwezig zijn. Een voorbeeld: sommigen meten bij patiënten met een beroerte het homocysteïnegehalte [11], maar zij doen dat alleen bij patiënten die niet roken en geen hoog cholesterol, hoge bloeddruk of diabetes hebben. Men denkt dus:de oorzaak van de beroerte is of dit óf dat, waarbij men zich geen rekenschap geeft van het concept 'deeloorzaak: Varianten wan dit probleem komen frequent en in vele gedaanten voor. Wie het concept deeloorzak gebruikt, is niet verbaasd te lezen dat bij longontstekingen frequent meer dan één microbiële verwekker een rol speelt [12]. Wie het concept deeloorzaak gebruikt, is beter in staat medische fouten te voorkomen. Een paar jaar geleden behandelde ik een jonge vrouw die vanwege een ernstige bloedvatontsteking elders behandeld was met afweerremmende medicijnen, waarbij de weekdosis abusievelijk als dagdosis was gegeven, die dus zeven keer te hoog was, hetgeen door de verwijzende artsen niet was opgemerkt. Het gevolg was ernstige remming van de afweer, waardoor patiënte een bloed- 
vergiftiging ontwikkelde en steeds zieker werd (het is overigens goed afgelopen). Nu kun je zeggen: de voorschrijvende arts is de oorzaak - die heeft de fout gemaakt. Maar dat was natuurlijk niet voldoende: de apotheek had de ongebruikelijke dosering kunnen opmerken; de verpleging idem; collega-artsen evenzo; en een wekelijkse grote visite met systematische revisie van de medicatie had de fout eveneens opgemerkt. Kortom: deeloorzaken, in dit geval: noodzakelijke deeloorzaken. En iedere noodzakelijke deeloorzaak is een kans op preventie. Wie het concept deeloorzaak gebruikt, beseft dat het contrast van 'erfelijke ziek. ten' tegenover 'niet-erfelijke ziekten' misleidend is. Fenylketonurie is een 'erfelijke' ziekte waarbij mentale retardatie ontstaat bij blootstelling aan fenylalanine (een aminozuur) in het dieet. Zonder de erfelijke afwijking geen mentalle retardatie, dus mentale retardatie bij fenylketonurie is '100\% erfelijk'. Maar zonder een dieet warin fenylalanine zit, óók geen mentale retardatie, dus mentale retardatie bij fenylketonurie is ' $100 \%$ niet-erfelijk'. Zonder blootstelling aan het humaan immunodeficiëntievirus geen HIV-infectie, dus HIV-infectie is '100\% niet-erfelijk'. Maar sommige individuen die herhaaldelijk aan HIV worden blootgesteld krijgen desondanks geen HIV-infectie, waarschijnlijk doordat zij een erfelijk bepaalde celreceptor voor HIV missen. De aanwezigheid van die receptor is kennelijk een noodzakelijke voorwaarde voor het oplopen van een HIV-infectie: een HIV-infectie is dus ' $100 \%$ erfellijk'. Indien men zich niet realiseert dat ziekten ontstaan door een ingewilkeld samenspel van erfelijke en niet-erfelijke factoren, blijven belangrijke kansen voor preventie en behandeling onbenut [13].

\section{Aanbeveling 2: besef dat ziekten niet bestaan en dat diagnostische crite- ria berusten op afspraken}

Ziekten bestaan niet. Ze worden niet 'herkend'. Wat wij een 'ziekte' noemen ontstaat door wat wij waarnemen aan patiënten in combinatie met onze opvattingen over de oorzaken daarvan. Wij zien, laten we zeggen, patiênten met koortsende ziekten die in wochtige omstandigheden leven en wij noemen dat moeraskoorts. Nu wordt de malariaparasiet ontdekt en van de moeraskoortsen splitsen wij malaria af; de rest heet nog steeds moeraskoorts. Maar dat betekent niet dat wij malaria als zlekte konden herkennen los van onze opvatting dat die parasiet daarbij een oorzakelijke rol speelt. Vervolgens zeggen wij: besmetting met die parasiet is noodzakelijk voor malaria. Zo ook: besmetting met de tuberkelbacil is noodzakellijk voor het ontstaan van longtuberculose en: besmetting met de meningokok is noodzakelijk voor het ontstaan van 
meningokokkenmeningitis, een vorm van nekkramp. Dit soort uitspraken zegt echter meer over de classificatie van ziekten en over de afspraken die wij daarover met elkaar hebben gemaakt, dan over ons inzicht in de deeloorzaken van moeraskoorts "longontsteking of meningitis Merk op dat de juistheid van diagnostische criteria afhangt van de juistheid van onze opvattingen over ziekteoorzaken. De genoemde voorbeelden laten immers zien dat onze opvattingen over oorzaken van een ziekte de criteria voor de diagnostiek van die ziekte bepalen.

Classificatie van ziekten is moeilijk doordat ons inzicht in de deeloorzaken van ziekten heel beperkt is. Het is instructief eens te kijken naar een vroege poging tot classificatie, in dit geval van diersoorten, in een oude Chinese encyclopedie getiteld Hemels Emporium van Welwillende Kerinis [14]: "Dieren zijn te onderscheiden in 1) toebehorend aan de Keizer, 2) gebalsemd, 3) getemd, 4) speenvarkens, 5) zeemeerminnen, 6) fabeldieren, 7) zwerfhonden, 8) die welke in deze classificatie zijn opgenomen, 9) die welke te keer gaan als dwazen, 10) ontelbare, 11) die welke zijn getekend met een heel fijn kameelharen penseel, 12) enzovoorts, 13) die welke net een vaas hebben gebroken, 14) die welke uit de verte op vliegen lijken." Dat vinden wij primitief, omdat onze inzichten in de samenhang van diersoorten sinds Darwin sterk is toegenomen. Malar vergelijk de $10^{e}$ versie van de international Classification of Diseases, van de World Health organisation, uit 1992, vrij vertaald: "1) Bepaalde infectieuze en parasitaire ziekten, 2) nieuwvormingen, 3) bloedziekten, 4) stofwisselingsziekten, 5) gedragsstoornissen, 6) ziekten van het zenuwstelsel, 7) oogziekten, 8) oorziekten, 9) bloedvatziekten, 10) ziekten van het ademhalingssysteem, [...], 15) zwangerschap, 16) bepaalde aandoeningen vlak na de geboorte, 17) aandoeningen bij chromosoomafwijkingen, 18) abnormale bevindingen die nergens anders onder vallen, 19) ongevallen en vergiftigingen $[. . .]^{\prime \prime}$. Hoe zal deze classificatie er over 30 jaar witzien, nadat inzichten verkregen uit genomics, proteomics en metabolomics zijn verwerkt? Dat zal afhangen van de vraag in hoeverre deze technieken ons in staat zullen stellen de pathobiologie van de hele mens beter te begrijpen, inclusief de talloze variaties daarin. Dat zou wel eens veel langer kunnen duren dan menigeen denkt. 
Aanbeveling 3: besef dat het concept van deeloorzaken en oorzakelijk complement tot gevolg heeft dat het biologische belang van een deeloorzaak voor het ontstaan van een ziekte niet kan worden afgeleid wit de sterkte van het verband tussen die deeloorzaak en de ziekte [8]

De sterkte van het verband tussen een deeloorzaak en een ziekte wordt bepaald door te vergelijken hoe vaak de ziekte voorkomt bij aanen afwezigheld van de deeloorzaak. Dat wordt wervolgens uitgedrukt als relatief risico of als risicoverschil, een absolute maat. De sterkte van dat verband hangt daardoor af van twee factoren. De eerste factor is de frequentie van voorkomen van het oorzakelijke complement. Besmetting met de tuberkelbacil leidt bij onderwoeding - een deel van het oorzakèlijke complement - veel vaker tot longontsteking dan bil goed gevoede mensen, en het verband tussen die besmetting en longontsteking is dus sterker bij ondervoeding. Maar dat zegt niets over het biologische belang van besmetting met de tuberkelbacil voor het ontstaan van longontsteking. (Het zegt wél liets over het praktische belang van die besmetting voor de volksgezondheid.) De tweede factor is de prevalentie van sets voldoende oorzaken die niet de blootstelling in kwestie bevatten ten opzichte van die sets die die blootstelling wél bevatten. Twee belangrijke deeloorzaken van hypothyreoildie (dat is een te langzaam werkende schildklier) zijn ontsteking van de schildklier en jodiurngebrek. In gebieden met veel jodiumgebrek is het verband van ontsteking met hypothyreoïdie zwak; in gebieden met weinig jodiumgebrek is het andersom. Wederom: dat zegt niets over het biologische belang van die ontsteking voor het ontstaan van hypothyreoildie.

We gebruiken dit soort kennis veelal impliciet, bij het schatten van de voorafkans op ziekte in een individuele patiēnt. Een twintigjarige, ondervoede, Somalische azielzoekster met vocht in de buik (ascites), kan heel goed een vorm van tuberculose, namelijk peritonitis tuberculosa, hebben. Bij een vijftigjarige vrouw van Nederlandse komaf zijn alcoholmisbruik of kanker van de eierstokken veel waarschijnlijker. Het gevaar nu is dat zwakke verbanden worden afgedaan als biologisch irrelevant. Het verband tussen homocysteinnespiegel en hartinfarct is gemiddeld niet ind rukwekkend. Dat sluit niet uit dat het voor sommige individuen zeer belangrijk is - bij hen is kennelijk het ons nog onbekende corzakelijke complement anwezig $[15,16]$. 


\section{Aanbeveling 4: wantrouw inductie en verificatie, vertrou w falsificatie [8]}

Onze opvattingen over oorzaken van ziekten blijken gebaseerd op inductie, dat wil zeggen dat wij door herhaalde observaties bij zieke en gezonde mensen generaliseren naar deeloorzaken van ziekten, een opvatting die teruggaat op de filosofen Francis Bacon en John Stuart Mill. En inderdaad: een patient krijgt diabetes en daarna een hartinfarct en wij concluderen: daardoor. Een patiènt krijgt huiduitslag na een antibioticum en wij concluderen: door het antibioticum. Een patient met hardnekkige hooikoorts heeft minder klachten na een homeopathicum en sommigen concluderen: door het homeopathicum. De haan kraait en daarna gaat de zon op: daardoor?

Inductie is geen goede basis voor oordelen over oorzakelijkheid

Er is niets mis met inductie als methode om ideeen op te doen over oorzaken van ziekten, maar inductie kan niet worden gebruikt om vast te stellen of een blootstelling A inderdaad een deeloorzaak is van zlekte $B$. De filosofen David Hume en Bertrand Russell hebben er overtuigend op gewezen dat inductie als manier van argumenteren, hoe ogenschijnlijk plausibel soms ook, berust op de irrationele aanname dat een B-na-Apatroon dat zich in het verleden heeft voorgedaan zich ook in de toekomst zal voordoen. Anders gezegd: er zijn geen eigenschappen waaraan wij oorzakelijke B-na-A-patronen kunnen herkennen en dus onderscheiden van niet-oorzakelijke B-na-A-patronen. 'Resultaten behaald in het verleden bieden geen garantie voor de toekomst.'

Hypothesen ower oorzaken van ziekten zijn wel weerlegbaar, maar niet bewijsbaar

De enig juiste, want logisch houdbare, redenaties over oorzakelijkheid ziljn die welke volgen uit de falsificatieleer van Karl Popper. Observaties kunnen consistent zijn met een hypothese over oorzaak en gewolg. maar observaties, hoe talrijk en consistent ook, kunnen een hypothese nooit bewijzen. Anderzijds kan één enkele observatie een hypothese wél weerleggen. Draai de haan zijn nek om en kijk of de zon dan nog opgat. We kumnen niet bewijzen dat roken longkanker veroorzaakt, maar we kunnen wél alternatieve verklaringen voor het verband tussen roken en longkanker weerleggen en dat is ook uitgebreid gebeurd. Daardoor is de veronderstelling dlat roken longkanker veroorzaakt de beste beschikbare verklaring voor de gegevens die voor ons liggen. We kunnen niet bewijzen dat diabetes hartinfarcten veroorzaakt, maar we kunnen wel alternatieve verklaringen weerleggen. Diabetes gaat bijvoorbeelul vaak 
gepaard met een hoge bloeddruk. De hypothese dat het verband tussen diabetes en hartinfarct verklaard wordt door een verhoogde bloeddruk kan worden weerlegd door aan te tonen dat het verband tussen diabetes en hartinfarct ók bestaat onder individuen met een normale bloeddruk, want bij hen speelt een verhoogde bloeddruk uiteraard geen rol.

Kunnen we echt niet bewijzen dat blootstelling A een deeloorzaak is van ziekte B?

Nee, dat kan écht niet. Ook de postulaten wan Koch 'bewijzen' niets, doordat het eerste postulaat een cirkelredenering bevat [17]. Dat postulaat luidt: 'Het micro-organisme moet in ieder ziektegeval aanwezig zijn.' Het circulaire aspect zit in 'in ieder ziektegeval', alsof ziekten herkend worden los van de ontdekking van micro-organismen. Dat is niet het geval.

Zijn er dan geen criteria op grond waarvan we kunnen besluiten of lets een deeloorzaak is van ziekte? Die bestaan wel, maar helaas zijn ze gebaseerd op inductieve redeneringen en daardoor onhoudbaar. De bekendste zijn die van de epidemioloog Austin Bradford Hitl: 1. sterkte wan een verband tussen mogelijke deeloorzaak en ziekte; 2 . consistentie van het verband onder verschillende omstandigheden; 3 . specificiteit van het verband: één oorzaak leidt tot één effect, en nlet tot meer dan één; 4. oorzaak komt vốr gevolg; 5 . biologische gradiënt, dat wil zeggen een monotone dosis-responsrelatie; 6 . plausibiliteit; 7 . coherentie met andere gegevens; 8 . experimenteel bewijs en 9 . analogie [18], Van deze criteria is alleen het vierde criterium houdbaar: oorzaak gaat vooraf aan gevolg $[8,19,20]$.

Het is natuurlijk wél mogelijk te 'bewijzen' dat een patiënt een ziekte heeft wanneer daarmee wordt bedoeld: voldoet aan de criteria die per afspraak die ziekte definiëren. De circulariteit hlervan is evident. Zo gauw die criteria ontbreken of controversieel zijn vervalt zelfs de mogelijkheid te 'bewijzen' dat een individu lijdt aan een ziekte (bijvoorbeeld het chronische-vermoeidheidssyndroom). En als de criteria, per afspraak, veranderen, zijn sommigen ineens ziek en anderen niet meer, zoals bijvoorbeeld is gebeurd bij diabetes, osteoporose en dementie.

\section{Gevolgen van de falsificatieleer voor wetenschappelijk onderzoek}

Goed wetenschappelijk onderzoek bestaat uit het afleiden van voorspellingen uit hypothesen en het vergelijken van deze voorspel- 
lingen met observaties wan de werkelijkheid. De hypothese moet zo zijn opgesteld dat ze weerlegbaar is door observaties. Vage hypothesen hebben namelijk wage gevolgen en die zijm moeilijk testbaar. Een goede hypothese genereert toetsbare en nauwkeurige woorspellingen, overleeft weerleggingspogingen en brengt veel obserwaties onder eén noemer. De consequenties van deze opvattingen woor wetenschappelijk onderzoek in de geneeskunde, en uiteindelijk woor klinisch handelen, zijn niet minder dan dramatisch. We hebben niets aan onderzoekers die hun favoriete hypothese willen 'bewijzen', want bewijzen is een illusie. Wetenschappelijke creativiteit bestaat uit doen van voorspellingen op grond van hypothesen en het bedenken wan onderzoek waarmee die voorspellingen weerlegd kunnen worden. Een goede hypothese over oorzaken van ziekte leidt tot voorspelbaarheid van waarnemingen en is testbaar.

Het is dus beter hypothesen te trachten te weerleggen dan observaties te herhalen en tot bewijs te verheffen. De vraag is niet of een verband tussen blootstelling en ziekte bewezen oorzakelijk is, maar welke andere hypothesen zoin verband kunnen verklaren en welke daarvan weerlegbaar zijn.

De uitdrukking 'poging tot weerlegging van een hypothese' heeft overigens geen emotionele lading en hoort die ook niet te hebben. Het geloof of ongeloof van de onderzoeker in een hypothese zegt immers niets over de juistheid ervan. Waarom het gaat is dat weerleggingspogingen informatiever zijn dan verificatiepogingen. Als een hypothese over ziekteoorzaken weerleggingspogingen overleeft, ondersteunt dat die hypothese méér dan als men nog eens zou aantonen dat het door de hypothese gepostuleerde verband tussen blootstelling A en ziekte B ook bestaat in, zeg, Maastricht, Meppel of Medemblik.

De juistheid wan een hypothese over oorzaken van ziekte is miet kwantifi. ceerboar

Zonder problemen is deze conclusie niet. In het afleiden van voorspellingen uit hypothesen zitten namelijk allerlei aannamen verborgen. Wij kunnen zulke aannamen wel onderzoeken en trachten te weerleggen, maar niet bewijzen. De valliditeit van onze conclusies hangt dus onlosmakelijk af van ons subjectieve geloof in zulke aannamen. Weliswaar kunnen wij, indien wij bereid zijn ons subjectieve geloof te kwantificeren, met de regel van de Engelse filosoof Thomas Bayes en de klassieke 
warschijulikheidsleer een valide schatting doen van de juistheid van onze conclusies, maar deze schatting blift een functie van ons initele, subjectieve geloof. De objectieve juistheid van een hypothese over deeloorzaken vari ziekte is niet kwantificeerbaar. Een hypothese die veet intelligente pogingen tot weerlegging heeft overleefd is een betere hypothese dan ét die zuke weerleggingspogingen niet heeft ondergaan, maar er bestaat geen systeem om uit te rekenen hoeveel beter. Dat is een belangrijk en vooralsnog onopgelost probleem [21].

Opvattingen over oorzaken van ziekten zouden in het geneeskundecurriculum en bij nascholingen weel explicieter aan de orde moeten komen dan nu gebeurt. Indien men daarbij warkelijk bestaande diagnostische en therapeutische adviezen als onderwijsmateriaal gebruilkt, leren studenten geneeskunde en medisch specilaisten, al dan niet in opleiding, niet alleen het nodige over allerlei aandoeningen, maar leren zlj bovendien kritisch denken over deze grondslag wan hun vak.

\section{Samengevat:}

- By thet denken over oorzaken van ziekten maakt men vaak twee fouten: men redeneert vanuit een concept van één ziekte, é̉n oorzaak; en men gebruikt inductieve redeneringen

- Er is een universeel toepasbaar denkmodel over oorzaken wan ziekten, met als kernconcepten deeloorzaak, woldoende oorzaak, noodzakelijke oorzaak en oorzakelijk complement

- Consequent toepassen van dit model zal belangrijke gevolgen hebben woor onderwijs in de geneeskunde, voor wetenschappelijk onderzoek, en voor patientenzorg

- Er zijin géén criteria waaralan kandidaat-deeloorzaken wan ziekten moeten voldoen opdat wij kunnen besluitem of iets een deeloorzaak is van een ziekte, behalve éën: deeloorzaak moet vooraf gaan aan zlekte

* Hypothesen over deeloorzaken van ziekten kunnen wel worden weerlegd, maar niet bewezen

\section{De zesde grondslag van de interne geneeskunde: effectief communice ren}

Onderwijs, opleiding, onderzoek, patiêntenzorg: alles is afhankelijk van effectleve communicatie. Daar wordt the wainig aandacht aan besteed. Wij weten bijwoorbeeld well dat patienten gewoonlijk grote moeite hebben het het concept 'kans' of 'risica', maar dat wil niet zeggen 
dat wij structureel aandacht besteden aan hoe een arts daarover moet communiceren.

Mijn stelling is dat de sleutel tot effectief communiceren ligt in de bereidheid en het vermogen van de spreker of de schrijver zich te verdiepen in de toehoorder of de lezer.

Het is goed voor onze bescheidenheid te beseffen dat dat beginsel, en de consequenties ervan, al ongeveer 1900 jaar geleden zijn wastgelegd in een dik leerboek. De schrijwer wan dat boek was Marcus Fabius Quintilianus [22]. Dat boek heet institutio oratoria. Het is een handboek voor de opleiding tot redenaar, geschreven in de jaren 92 tot 95 van onze jaartelling. Marcus Fabius Quintilianus was een in Noord-Spanje geboren Romein, die in 69, na de moord op Nero, met de keizerskandidaat Galba uit Spanje naar Rome kwam en die de eerste was die een onder Vespasianus ingestelde en van staatswege bezoldigde leerstoel in de retorica bekleedde, een hoogleraar communicatiewetenschap zouden we nu misschien zeggen. Wat Quintilianus heeft opgeschreven over effectief communiceren is voor ons nog steeds relevant. Ik zal dat illustreren aan communicatie in de wetenschap.

Quintilianus' institutio was het resultaat van vijf eeuwen theorievorming over en onderwijs in de welsprekendheid. Invloed in het Grieke en Romeinse leven van die tijd was in belangrijke mate gebaseerd op het vermogen anderen te overtuigen van de eigen standpunten, en daarbij spelen argumentatie en stijl een hoofdrol. En zo is het in de medische wetenschap van nu ook. Wie denkt dat de koele feiten voor zichzelf spreken vergist zich: of een manuscript in een prestigieus tijdschrift wordt gepubliceerd hangt wel degelijk medle af van de manier waarop de argumenten worden gerangschikt en verwoord.

De redenaar, zo ook de schrijver wan nu, heeft volgens Quintilianus drie taken. Hij moet zijn gehoor of zijn lezers informeren, hil moet onderhoudend zijn - je moet het niet gortdroog en stomvervelend opschrijwen: een kwestie van stijl dus - en hij moet de emoties van zljn publiek bespelen. Niet woor niets vindt men in de inleiding wam een artikel of subsidieaanvraag over aandoening $X$ gewoonlijk de informatle dat $X$ vaak voorkomt, (desnoods in een klein deel van de bevolking, maar daar dän ook héél vaak!), en dat bovendien $x$ een héél erge ziekte is - de schrijver tracht emoties op te wekken bij de lezer, die immers wordt uitgenodigd zich te 
realiseren dat de lijders aan ziekte $X$ inderdaad beklagenswaardig zijn, en - bij uitbreiding - dat het betoog dat nu komt de aandacht van de lezer meer dan waard is, of het geld van de subsidiegever, et cetera.

Een redienaar doorloopt vijf fasen:

1. Vinding (inventio): wat; standpunten; argumenten

2. Ordening (dispositio)

3. Verwoording (elocutio)

4. Geheugentraining

5. Voordracht

Daarvan zijn de eerste drie van rechtstreeks belang woor de schrijver. De winding is het bedenken hoe de zaak moet worden aangepakt; wat de grondvraag is; wat de standpunten zullen zijn en welke de argumenten. Bij de ordening plaatst de schrijver alle bij de winding opgespoorde elementen in de juiste volgorde en doet dat op een stilistisch passende manier: dat laatste heet de verwoording.

Wat betekent dat nu voor de wetenschappelijke artikelen van nu? lk zal w een paar voorbeelden geven. Er zijn verschillende soorten artikelen, zoals overzichtsartikelen, bijvoorbeeld de "verhalende" en de 'systemati. sche', en zogenoemde oorspronkelijke artikelen - in die laatste worden nieuwe feiten aangedragen, en de lezer moet worden overtuigd niet alleen van de juistheid van die feiten maar ook van hun relevantie. De opbouw van die oorspronkelijke artikelen ligt vast - daar zijn internationale afspraken over.

Opbouw van een 'oorspronkelijk artikel":

1. Titel

2. Samenvatting

3. Inleiding

4. Methoden

5. Resultaten

6. Bespreking

7. Literatuurverwijzingen

Quintilianus benadrukt voortdurend dat de spreker in dialoog is met zijn gehoor - en de schrijver met zijn veronderstelde lezers. Men moet zich dus een beeld vormen van wie de lezer is. Wat interesseert hem? Wat zijn zijn opvattingen? Dat zijn lastige vragen en ik kom daar 
nog op terug. Maar éen ding staat vast: de lezer van nu heeft haast. En daarom zijn declaratieve titels zoals 'De lezer heeft haast' meestal beter dan descriptieve zoals 'De lezer en zijn tijdsbesteding. Want declaratieve titels laten de lezer meteen zien waar de schrijver naartoe wil, waar de schrijver de lezer van will overtuigen. Dat scheelt tijd.

Nu een paar opmerkingen over de Inleiding. Die levert vaak veel pro blemen op. Dat is niet verwonderlijk, want het complete probleem van de vinding moet worden opgelost voordat de Inleiding goed op papier kan komen. Wat will ik zeggen? En wat zijn de argumenten? De belangrijkste fout die beginners maken is dat zij in de inleiding opsommen wat zij zelf allemaal recent geleerd hebben - zij verliezen dus hun lezers uit het oog, want die weten veel daarvan al. In plaats daarvan doet een goede inleiding drie mededelingen, en meestall ook niet veel meer dan drie, namelijk (n) $X$ is een belangrijk probleem; (2) om $X$ op te lossen is (onder meer) $Y$ nodig; (3) wij hebben $Y$ woor $u$ uitgezocht, en daar doet dit artikel verslag van.

Merk op dat (1) en (2) stellingen zijn en ondersteund moeten worden door argumenten. Daarover zegt Quintilianus werkelijk allerlei behartenswaardigs. Bijvoorbeeld:

- Geef niet te veel argumenten: tijd en aandachtsboog van de toehoorders zijn beperkt.

- Zorg dat de argumenten relevant zijn en ondersteunend; zaai geen twijfel. Wees, als het even kan, dus niet 'even handed'l Dok zwakke argumenten kun je beter weglaten, want die zaalen ongewenste twijfel omtrent de juistheid van de stelling.

- Argumentatie is een dialloog met het publiek.

- Geef eerst de stelling, dan de argumenten en niet andersom. Dat is namelijk veel gemakkelijker voor de lezer. Als ik zeg: 'de zaal zit vol en het publiek luistert aandachtig, dan weet $u$ nog niet waar ik naartoe wil. 'Daarom ben ik tevreden' komt dus als verrasising. De omgekeerde volgorde - 'ik ben tevreden, omdat', et cetera, is gemakkelijker voor u. Dus, dames en heren internisten in opleiding, als u overdraagt, zoals op een ochtendrapport, dan moet u beginnen met een werkdiagnose, met daarna de argumenten, want dan vergt $u$ minder van uw gehoor. Om dezelfde reden adviseert Quintilianus uitweidingen aan het eind te geven, niet aan het begin.

- De dialoog moet beginnen, moet gebouwd worden op stellingen die al door het publiek aanvaard zijn: van aanvaarde stellingen (let- 
terlijk loci communes = gemeenplaatsen) via argumenten naar de conclusies (de nieuwe stellingen die de schrijuer door het publiek aarvaard wil zien). Gooi, in deze fase, geen heilige huisjes omver van zelfs maar een deel van je lezers In het begin moet de lezer welwitlend en geïnteresseerd gestemd worden.

Quintilianus geeft uiteraard ook allerlei adviezen over taalgebruik. Ook daarbij benadrukt hij woortdurend dat het de toehoorder zo gemakkelijk mogelijk gemaakt moet worden het betoog te volgen. Wetenschappelijke artikelen van nu worden in het Engels geschreven - het Latijn van onze tijd. Dat stelt ons veelal voor speciale problemen, want Engels is niet onze moedertaal. Wie effectief Engels wil schrijven, ontkomt er niet aan zich te verdiepen in de nuances van die taal voorzover dat ons helpt de lezer duidelijk te maken wat wij willen betogen.

Ik geef twee voorbeelden. Ten eerste: het Engels kent een hele waaier van zogenoemde "verbindingswoorden" (transition signals), die zinmen aan elkaar knopen, en die de functie hebben het de lezer makkelijker maken de gedachtegang van de schrijver te volgen. Het Engels zet die bovendien veelal aan het begin wan een zin. Het is verstandig dit soort verbindingswoorden frequent te gebruikem - je maakt het de lezer gemakkelijker.

Verbinding

In addition,...

Furthermore,

First and foremost,....

However,

For example,...

in other words,...

Therefore...
Argument is:

soortgelijk

belangrijker

belangrijkste (in rij)

tegengesteld

woorbeeld

herhaling

conclusie 
Ten tweede: de gevoelswaarde van de tijden van een werkwoord. In dit voorbeeld

An increase in air pollution

results

has resulted

resulted

in an increase in allergy sufferers.

zullen velen van u wellicht menen dat steeds min of meer dezelfde mededeling wordt gedaan - een toename van de luchtvervuling resulteert in een toename van het aantal lijders aan allergieèn. Maar dat is niet zo. De gevoelswaarde is heel verschillend:

An increase in air pollution

$\begin{array}{ll}\text { results } & \text { altijd en overal } \\ \text { has resulted } & \text { redelijkerwijs } \\ \text { resulted } & \text { zoukunnen }\end{array}$

in an increase in allergy sufferers.

In het Nederlands zal al gauw de onvoltooid tegenwoordige tijd gebruikt worden, maar dat geeft in het Engels een mate van zekerheid weer die er vaak niet is, en dus kan irriteren: wees voorzichtig daarmee en strijk je lezers niet onnodig tegen de haren in zou Quintilianus zeggen. 
Geachte toehoorders, ik heb gesproken over zes grondslagen van de interne gerieeskunde: 1) het proces van klacht naar diagnose en behandeling; 2) het rekening houden met de variatie tussen individuen; 3) het selecteren, woor de individuele patiënt, van de juiste diagnose en behandeling: 4) de organisatie van patiëntenzorg, opleiding en nascholing; 5) de opvattingen over oorzaken vain ziekten; en 6) de effectiviteit van communicatie. Ik ben ervan overtuigd dat vooruitgang in de geneeskunde afhangt van de mate waarin wij op deze terreinen betere inzichten verwerven en implementeren in ons dagelijks handelen.

Zes grondslagen, zes uitdagingen lik aanvaard die met plezier en optimisme, orndat ik mij binnen de afdeling Interne Geneeskunde omringd weet door getalenteerde staf, artsen in opleiding en onderzoekers, en door gemotiveerde ondersteunende medewerkers. Die afdeling is ingebed in een jong, ambitieus academisch zieken huis en een jonge, a mbitieuze universiteit, de besturen waarvan ik oproep nóg meer dan $z i j$ nu al doen gebruik te maken van, en te investeren in, de talenten en ambities van de medewerkers van de Interne Geneeskunde. 


\section{Dankwoord}

Ik dank het College van Bestuur van de Universiteit Maastricht en de Raad van Bestuur van het academisch ziekenhuis Maastricht woor het in mij gestelde vertrouwen.

Ik dank mijn klinische en wetenschappelijke leermeesters: Bob Silberbusch, Andreas Fischer, Jan van der Meer, Ab Donker, Lex Bouter en Nico Westerhof. Beste $A b$, wat ik jou verschuldigd ben is te veel om hier te noemen.

Ik dank alle medewerkers wan de Interne Geneeskunde woor het woorrecht met u samen te werken. Ik zal mijn best doen uw talenten en ambities ruimte te geven.

Begeleiden van getalenteerde mensen is misschien wel het aantrekkelijkste aspect van werken aan een universiteit. Ik dank mijn promovendi en promovendae, zowel diegenen wier proefschrift voltooid is [Marchien van Baal, Annemarie Becker, Michiel van den Berg, Bastiaan van Dam, Hester Daeimans, Rob van Dijk, Ed Erínga, Isabel Ferreira de Sousa; Erik Giltay, Coen van Guldener, Ellen Hoogeveen, Frans van Ittersum, Agnes Jager, Sylvia de Jong, Jan Lambert, Miranda Schram, Erik Serné, Ronald Smulders, Wvo Smulders, Gerdien de Valk-de Roo, Erik Vermeulen, Michiel Wulffelé en Richard IJzerman],

als diegenen wier proefschrift nog niet voltooid is [Wineke Bakker, Martijn Brouwers, Marja van Eer, Mohamed Hadithi, Manon van Hecke, Ronald Henry, Jolien de Jager, Renate de Jongh, Iris Ketel, Koen van der Kooy, Steven Meex, Prabath Namayakkara, Stephan Praet, Samyah Shadid, Angélique Spoelstra-de Man, Frank Stam en Abel Thijs].

Mijn onderzoeksinteresse betreft de vasculaire complicaties van metabole ziekten, iets wat alleen door een multidisciplinaire aanpak kan worden ontrafeld. Voor zo'n aanpak is samenwerking tussen basale wetenschappers, clinici en epidemiologen essentieel. Casper Schalkwijk. hoofd van het laboratorium Interne Ceneeskunde, speelt daarin een sleutelrol. Ik dank daarnaast in het bijzonder de hoogleraren Dorret Boomsma, Lex Bouter, Nish Chaturvedi, Henriette Delemarre-van der Waal, John Fuller, Rijk Gans, Louis Gooren, Rob Heine, Peter Huijgens, Victor van Hinsbergh, Karel Jakobs, Han Kemper, Peter Kenemans, Harm Kuijpers, Willem van Mechelen, Hans Niessen, Hans-Henrik Parving, 
Bettine Polak, Martin Prins, Jan Rauwerda, Piet ter Wee, Nico Westerhof en John Yudkin, en de zeergeleerden Henk Billo, Ellen Blaak, Jacqueline Dekker, Angelika Dräger, Sjef Emeis, Edith Feskens, Mari-Anne Gall, Marleen van Greevenbroek, Boy Houben, Maya Huijberts, Carla van der Kallen, Otto Kamp, Adriaan Kooy, Plet Kostense, Teake Kooistra, Lue van Loon, Kees de Meer, Jan van der Mooren, Coen Netelenbos, Nicolaas Schaper, Piet Sipkema, Annemieke Spijkerman, Lise Tarnow, Tom Teerlink, Jos Twisk, Mirfám van Weissenbruch en Jacquelline Witteman.

Lleve vader en moeder: zonder jullie stond ik hier niet.

Lieve Beatrijs, Coen, Juliette, Lucas en Esther: zonder jullie ben ik niets.

Ik heb gezegd. 


\section{Noten}

ง. Zie bijwoorbeeld:

a. Wiersma T. Twee euwen zoeken naar medische bewijwoering. Amsterdam: Boom. 1999

b. Meer I van der. Zlekten bestaan niet. Afscheidsrede bif ajn aftreden als hoogleraar in de inwendige geneeskunde aan de wrije Unverstent. Amsterdam, Vu Boekhandel Uitgeveri, 2000

2. Saver $\| L_{2}$ Kalafut M. Combination therapy and the theoretical limitations of evidence based medicine. Neuroepidemiol agy 2001:20:57 64.

3. Zle:

a. Rothwell PM. Treating individuals 1. External validity of randomised controlled trials: "To whom do the results of this trial apply?" Lancet 2005:365:82-93.

b. Rothwell PM. Treating individuals 2. Subgraup analysis in randomised controlled trials: importance, indications, and interpretation. Lancet 2005365:176. 86.

c. Rothwell PM: Mehta Z, Howard SC, Gutnikov SA. Warlow CP. Treating individuals 3 . From subgroups to individuals: generat principles and the example of carotid endarterectomy. Lancet 2005:365:256-65.

4. Zie bijwoorbeeld:

a. Pauker $5 \mathrm{C}_{3}$ Kassiner $\mathrm{P}$. The threshold approach to dinical decision making. N Engl I Med 1980;302:1109-17.

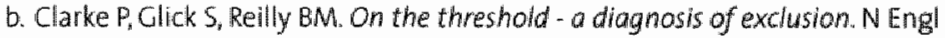
I Med 2005:35:2:919-24.

5. Zie bijwoorbeeld:

a. Weingarten $S R_{0}$ Lloyd $L$, Chlou $C F$ Braunstein GD. DO sidbspecialists working outside of their specialty provide less efficient and lower-quality care to hospitalized patients than do primary care physiciams? Arch Intern Med $2002 ; 162: 527-32$.

b. Redelmeier $\mathrm{D} \mathrm{A}, \mathrm{Tan} \mathrm{SH}$, Booth $\mathrm{GL}$. The treatment of unrelated disorders in patients with chranic medical diseases. N Engl I Med 1998;338:1516-20.

6. Zie:

a. Stehouwer CDA. De oorzaak ontmaskerd? (oratle). Amsterdam: VU Boekhandel/ uitgeverij, 2001.

b. Stehouwer CDA. Veronderstellingen over borzaken wan ziekte zign wel weerlegbaar, maar niet bewijsbaar. Bijblijwen 2002;18(6):39-46.

7. Zie:

ai. Kwallteitsinstituut voor de Gezondheidszorg CBO (CBO). Herziening consensus Urimeweginfecties. Utracht: $C B O, 1999$.

b. Broek Pl wan den, Everdingen JIE van. CBO-richtinem 'Urimeweginfecties. Ned Tijdschir Geneeskd $1999,43: 2461-5$. 
c. Timmermans AE, Barelier PJAM, Winkens RAG, Arets H. Whersma T. WHGstandaard Urineweginfecties. Husarts Wet 1999.42:613-22

d. Wersma 1), Timmermans AE. Samenvating van de standaard "Unineweginfectles" (eerste heriening) van het Nedetands Huisartsen Genootschap. Ned Tijschr Geneeskd 2001;45:735-9.

e. Meiman Fi. De standaard 'Urineweginfecties' wan het Nederlands Husartsen Genootschap; reactie vanut de huisartsengeneeskunde. Ned Tijdschr Geneeskd 2007:45:716-7.

f. Brodk pl van den. De standaard Urineweginfecties" van het Nederiands Huisartsen Genootschap; reactie vanuit de interne geneeskunde. Ned Tijdschr Genceskd 2001; $45: 748-20$.

g. Wiersma TI. Richtlinen voor de diagnostiek van urineweginfecties: voor- en nadelen van verschillende strategieën. Ned Tijdschr Geneeskd 2001;145:720. 6.

8. 21:

a. Rothman KJ. Causes. Am J Epidemiol 1976:104:587-92.

b. Rothman KJ, Greenland S. Causation and causal inference. In: Rothman KJ. Greenland $S$ (eds). Modern epidemiology, 2nd ed: 7-28. Philadelphia, PA: Lippincott-Raven Press, 1998.

9. Deeloorzaken en visicofactoren

De term 'deeloonaak' wordt in de literatuw niet wak gebruikt. De termen "risicofactor" en "risico-indicator' zijn gangbarder. Met de term 'risicofactor woor een zlekte' bedoelt men meestal een deeloorzaak van die ziekte. De term 'risicofactor' heeft dan dus een oorzakelijke connotatie. indien men zo'n connotatie wil vermijen gebruikt men de neutrale termen risico-indicator of risicomerker. Sommige auteurs gebruiken, en dat is verwarrend, de aanduiding "risicofactor" echter zonder oorzakelijke connotaltie. Ook de termen "determinant van ziekte' en 'voorspeller van ziekte' worden soms in oorzakelijke zin gebruikt en soms niet.

\section{Deeloorzaken van ziekte en risico op ziekte}

Een bercerte of een hartinfarct komt voor bij sommige mensen met een hoge bloeddruk of een hoog plasmacholesterol, maar lang net bij allen. We lezen dan ook valu uitspraken van het type: een 50 -jarige man die rookt, een hoge bloeddruk heeft en een hoog plasmacholesterol heeft een kans van $25 \%$ om In de komende 10 Jaar een hartinfart of een beroerte te krijgen: Zulke risicoschattingen zijn gebaseerd op observaties van groepen individuen. Maar de man die tegenover $u$ of mij in de spreekkamer zit "heeft niet een kans op hartinfarct of beroerte van $25 \%$ ijn kans is of o\% of 100\%. De verklaring van deze paradox ls dat wij onvoldoende weten over de deelooraken wan hartinfarct en beroerte onder 50 -jarige mannen met de genoemde eigenschappen Indien wij erin slagen meef deeloorzaken van hartinfarct en beroerte te identifceren zal onze risicoschatting nauwkeuriger worden, dat wil zeggen: de groep mannen tegen wie wij nu nog moeten zeggen dat zij een risico hebben 
van $25 \%$, 2all kunnen worden verdeeld in een groep met een (veel) hoger en een groep met een (weel) lager risico. Aan dit soort risicoschattingen en de mainter waarop ze worden gebruikt ztten echter nog veel haken en ogen [9a,g6]:

a. Stehouwer COA. Beleidsadwezen aon artsen en conomische owenwegingen daarbij: verdiensten en bezwaren. Ned Tijdsch Geneeslkd v999:43:776-8 (correspondentie: $1999,1433: 874-5$ ).

b. Smulders YM, Spljkerman AMW, Kostense Pf, Bouter LM, Stehouwer CDA. Oude en nieuwe scoresystemen voor het schatten wan cardiovasculloire risicos: beperkingen in de validiteit, de precisie en de homogenteit van de viricocategorieën. Ned Tijdschr Geneeskd $2004 ; 148: 2480-4$.

10. Papermaster DS. Necessigy but insufficient. Nature Med 1995;1:874-5.

11. Stehouwer CDA. Clinical relevance of hyperhomacysteinatmia in atherothrombotic disease. Orugs Aging 2000; $6: 251-60$.

12. Braun J. Graaff CS de, Goy J de, Zwinderman AH, Petit PLC. Buiten het zhekenw huis opgelopen pneumonie: verwekkers en beloop bij patiënten opgenomen in een algemeen ziekenhuis: Ned Tijdschr Geneeskd 20044:48:836-40.

13. Ziekten hebben deeloorzaken en verschillende verzamelingen deeloorzaken vormen verschillende woldoende oorzaken. Gevolg is dat de fractie ziakte die kan worden toegeschreven aan de som wan de deeloorzaken in alle mogelijke voldoende oorzaken als theoretische limiet 'oneindig" heeft en dus niet "100\%" $[8 \mathrm{a}, 8 \mathrm{~b}]$. De fractie ziekte die kan worden toegeschrewen aan een noodzakelijke deeloorzalk is $100 \%$ en dat geldt woor iedere noodzakelijke deeloorzak. Uitspraken van het type $z$ lekte $X$ heeft voor $80 \%$ erfelijke en woor $20 \%$ nieterfelijke oorzaken"hebben dan ook geen logische basis. Erfelike en niet-erfelijke factoren zijn deeloorzaken wan alle ziekten.

14. Geciteerd in: Flier F. Nosologie, noodzakelijkheid en de natuurlike soort. (Proefschrift) Uitgeverij KU Nijmegen, 1996:80-1.

15. Zie:

a. Homocysteine Studies Collaboration. Homocysteine and risk of ischemic heart disease and stroke. A meta-analysis. JAMA 2002;288:2015-22.

b. Hoogeveen EK, Kostense PI, Jakobs C, Dekker JM, Nijpels G, Heine RI, Bouter LM. Stehouwer CDA. Hyperhomogystememia increases risk of death, expeclally in type 2 diabetes: syear follow-up of the Hoom Study. Circulation 2000; $10117506-11$.

C. Becker A, Kostense PJ, Bos $G_{1}$. Heine RI, Dekker JM, Nijpels $G_{1}$ Bouter LM. Stehouwer CDA. Hyperhomacysteinaemia is assaclated with cononary events in type 2 diabetes. I Intern Med 2003:253:293-300.

16. De sterkte wan werbanden tussen deeloorzaken en ziekte $1 s_{\text {i }}$ van anderzoek tot onderzoek, lang niet altigd consistent. Dat is goed te begripen. Immers: 
variatue in het vớrkomen van sets voldoende oorgaken en wan het oorake. lijke complement van specifieke deeloorzaken kan zorder moeite verklaren wardoor de sterkte van en verband tussen deeloorzak en ziekte niet altid hetzelfde is. Twee voorbeelden illustre ren dat stel verschillende onderzokers, $A$ er $B$, doen onderzoek naar het verband tussen lange viegreizem en hell ontstaan van een trombosebeen of een longembolie, dat wil zeggen uitingen van het antstaan van blaedstolsels in de aderen. Zonder dat zij dat weten: doet A onderzoek onder individuen bij wie vak een erfeligke aanleg voorkomt voor het wormen vain bloedstolsels, en $B$ onder indwiduen bij wie zon aanleg heel weinug wook komt. Nu blijkt dat. A een sterk verband windt tussen lange vliegreizen en trombosebeen en longembolie, en $B$ in het geheel geen verband. Dat zagt niets over het biologisch belang van lange wilegreizen voor het ontstaan van bloedstolsels, want het is best mogeljk dat dat verband afhangt van het bestaan van zon erfelike aanleg, kortom van de frequentie van de aamwezig. heid wan het oorzakelijke complement van de deeloorzaak "lange viegreizen". Een tweede voorbeeld: diabetes wordt algemeen a angemerkt als een deeloorzaak wan hart-en vaatziekten. Indien men echter onderzoeken op een rijute zet waarin de sterkte van dat verband wordt geschat, bliken de resultaten forse warlatie te tonen. Een onderzoek wan Haffner al. uit 1998 liet zien dat het risico op hart-en vaatziekten bij patiënten met diabetes maar zonder een eerder hartinfarct ongeveer gelijk was aan dat wan patienten zonder diabetes maar met een eerder doorgemaakt hartinfarct [ $46 \mathrm{a}$ ]. Die bevinding heeft grote inwoed gehad op richtlijnen woor de behandeling wan diabetes. Wiij hebben nagekeken of wij de resultaten wan Haffner et all konden repraduceren onder Nederlandse diabetespattënten [16b]. Dat was mal gedeeltelijk het geval. namelifk wél onder wrouwen met diabetes, maar niet onder mannen. Helaas zal het weinig verbazing wekken dat wij dit "politiek incorrecte' resultat pas ma zeer grote vertraging konden publiceren. Inmiddels hebben andieren onze resultatten bevestigd [16c]. Dat betekent owerigens niet per se dat waffner et al. het mis hadden: zullke resultaten kumnen wan bevolking tot bevolking verschilten door verschillen in het woorkomen wan het oorzakelijke complement. Maar het deel van de richtlijn ower diabetesbehandeling dat betrekking heeft op deze kwestie ('hoe hoog is het risico op hart-en watziekten bij diabetes') is. voor de Nederlandse situatie, dus feitelijk gebaseerd op discutabele gegevens. (Erg is dat in dit geval niet, omdat de richtijm, hoewel deels discutabel, de tendens tot onderbehandel ing van diabetespatienten tegengat.) Niettemn deze bevindingen illustreren eenwoudigweg dat wij het oorzakelike complement van diabetes in het veroonaken van hart en vatziekten niet woldoende kennien. Het onkennen van zulke complexiteit is wellicht op korte terminn verleldali $k$, maar uiteindelijk in niemands belang, en zeker niet in dat wan de patient. indien wij beter zouden begrijpen welke diabetespatienten een hoog risico hebben op hart- en vatziekten, en welke een la ag, dan zouden wij de behandeling kunnen individualiseren: intensiever bij de eerste groep en - net zo belangrijk - minder intensiref bi de tweede groep.

a. Haffner SM, Lehto $S$, Rönnemaa $T$, Pyörälä $K$, Laakso M. Mortality from coronary heart disease in subjects with type 2 diabetes and in nondiabe- 
Wh subjects with and without prior myocardial inforction. $N$ Engl I Med $1998 ; 339: 229-34$.

b. Becker A, Bos $G$, Vegt F de, Kostense P., Dekker M, Nijpels G, Heine RI, Bouter LM. Stehouwer CDA. Cardiovascular events in type 2 diabetes: comparison with nondiabetic individuals without ond wh pritor cardiovascular disease. Ten-year follow-up of the Hoom study. Eur Heart $2003 ; 24: 406-13$.

c. Hu G, Jousilanti P, Qiao Q. Katoh S, Tuomilethto J. Sex differences in cardiovascular and total mortality amorg diabetic and non-diobetic individuals with or without history of myocardial infarction. Dlabetologia 2005;48:856-61.

17. MacMahon B, Pugh TF, Causes and entities of disease. M: Clatk DW, MacMahon B (eds). Preventive Medicine, 1st ed: 11-8. Boston MA: Little, Brown, 1967.

18. Hill $\mathrm{AB}$. The enwironment and disease: association or causation? Proc Royal Soc Med 19:65:5:8:295-300.

99. Ten aanzien van de overige criteria beperk ik mij hier tot enige opmerkingen ower experimenteel bewijs, ond at velen dat wél beschouwen als een objectief criterium woor causaliteit. Het is een cliche om op te merken dat heel veel hypothesen in de geneeskunde niet experimenteel benaderbaar zijn, zoals de hypothese: 'roken veroorzaakt bij mensen longkanker'. Dus als een hypothese al experimenteel bewijsbaar zou zijn, dan nog zou dat slechts voor een beperkt aantal hypothesen toepasbaar zinn. Maar zelfs die zekertheid hebben wij niet.

Een experiment, of dat nu in vitro plaatsvindt, of bij dieren of bij mensen, verschilt namelijk van niet-experimentele warnemingen in de mate van controle die de experimentator kan uitoefenen, dat wil zeggen: de mate waarn de overige omstandigheden gelijk kunnen worden gehouden. Het: verschil is dus kwantitatief en ongetwiffeld is dat soms van groot belang. maar het verschil is niet kwalitatief. En omdat men niet kan bewijzen dat alle relevante overige omstandigheden inderdaad constant zijn gehouden, is ook experimenteel bewijs geen houdbaiar objectlef criter lum voor causaliteit. Een voorbeeld: zogenoemd gerandomiseerd en placebogecontroleerd onderzoek wordt beschouwd als methodologisch het beste experimentele onderzoek dat bij mensen mogelijk is. Verscheidene van zulke onderzoken naar het effect van behandeling met statinen hebben aangetoond dat zon behandeling gepaard gaat met een duidelijke vermindering van de kans op een hartinfarct. Velen menen dat met dit experimentele bewijs definitef is a angetoond dat een hoog plasmacholesterol een deeloor a ak is van liartinfarcten. Vervolgens bleek echter dat statinen, naast het werlagen wan het plasmacholesterol, nog allerlei andere effecten hebben die warschijnlijk een rol spelen bij het woorko. men van hartinfarcten. Kortorn: in het stat menonderzoek, voorzover bedoeld om de hypothese te testen dat werlagen van plasmacholester ol hartinfarcten workomt; was het niet gelukt allie omstandigheden behalve het plasmacholesterol constant te mouden. 
Men kan won onderaek natuurlik pragmatisch interpreteren en zeggen: Als ik bij een patient de kans, op een hartinfarct wil werminderen, adviseer ik behandeling met een statine; want dat is experimenteel getest en de onderliggende oorakelyke structuur kan mij niet schelen. Maar de boter die men in de suparmarkl koopt an watop stat "helpt het cholesterolgehatte te wer. lagen', koopt men met orndal getesti is dat die boter hartinfarcten wookom: want dat is niet het geval, maar omda men wertrouwt op de redenering 'wat het tholesterolgehalte werlaagt, zal ook bijdagen aan het woorkomen van hartinfarcten", kortom: men vertrouwt op een onderliggende oorzakelike structuur die gebaseerd is op onder meer de interpretatie van het statinenonderaek interpretatie en toepassing van experimenteel onderzoek bij mensen kan miet los gezlen worden wan opvattingen ower de onderliggende oorzakelijke structurur.

20. Het gerandomiseerde en gecontroleerde experiment (randomised control. led trial, RCT) is woortgekomen wit de antwikkeling van de toetsende en schattende statistiek. Het denken over RCT's als experiment: wordt daardoor gedomineerd door statistische owerwegingen. Men kan zich afvragen of RCT's te wergelijken zijri met fysilologische experimenten zoals Claude Bernard die deed. Volgen sommigen is dat niet 20 [9:. Eer "echt" fyslologisch experiment, in deze opvatting, wergt experimentele contrale wan alle relevante factoren, ondat alleen zó het effect wan de te manipuleren factor kan worden vastgesteld. Dit effect kan in beginsel aan én enkele waameming worden vastgesteld. Reproduceerbaarheid dient om aan te tonen dat alle relevante verstorende factoren inderdaad geneutraliseerd zijn. Daarentegen zou een RCI onwolledige controle als gegeven accepteren, mar het effect daarwan onschadelijk maken door randomisering. Het effect wordt vastgesteld door vergelijking van groepen. un dezelfde geest zijn pogingen ondernomen "fysiologische" en "epidemiologische" causaliteit te onderscheiden, waarbij de eerste zou worden gekenmerkt doar grotele "connectiviteit" wan oorzaak en gevolg, en door grotere horrogeniteit van de onderzochten [1a, p275f]. Deze argumentatie overtuigt mij niet. "Totale" controle van andere variabelen in een "fysiologisch experiment" is ombewijsbaar (en lijkt mij illusoir), net als in een RCT. Reproduceerbaarheid en generaliseerbatheid moeten zowel voor " "fysiologische experimenten" als woor RCT's empirisch getoetst worden. RCT's worden gewoonlijk dan ook 'oorzakelijk-fysiologisch' geinterpreteerd, onder meer doondat zi voortwloelen wit fysiologische concepten oat lijkt mij juist. (Hoewel niet zonder gevar. Zo worden pragmatische selectiecriteria ók waak fysiologisch geinterpreteerd, en dat is geheel ten onrechte als die selectiecri. terla nlets the maken hebben met de onderliggende (veronderstelde) oorzakgevolgverbanden.)

Een ander verschil tussen experimenteel en observationeel onderzoek is $\mathrm{dat}$ bij experinerten, de experimentator, en niet het individu, de te onderzaeken variabele manipuleert. In de praktijk betekent dat veelal dat in een experiment meé potentieel verstorende varlabelen geélimineerd kunnen worden 
dan bij observationeel onderzok. Maar ook dit verschil lijkt mij gradueel en niet principieel

21. Ik geef hier nog enige woor de geneeskunde relevante details over en gevolgen van de falsificatieleer.

a. Falsificatie heeft betrekking op uniwersele stellingen "all swans are white"; "diabetes veroorzakt blindheid"), miet op existentiele ("there exists at least one black 5 wan": er bestal tenminste én patient met diabetes die blind is"). Bij epidemiologisch onderzoek gat het er in de eerste plats om te trachten de hypothesen te werwerpen dat de bevindingen berusten op 1 ) toevalsfouten bij het samenstellen van de onderzoekspopulatie; 2) fouten bij het meten wan de determinanten of de uitkomsten; 3) verwarng met het effect van een andere determinant en (of) 4 ) een mengsel van verschillende effecten in verschillende subgroepen

b. In een situatie met slechts twee, complementaire hypothesen $A$ en $B$ bestaat geen verschil tussen weerleggen van $A$ en bewijzen van $B$, maar in de geneeskunde bestan altijd veel alternatieven voor $A_{8}$ en doet deze symmetrie tussen weerleggen en bewijzen zich dus niet woor.

c. Deze opvatting dat hypothesen in de geneeskunde niet bewezen kumnen worden, hoeft niet te leiden tot verlamming waar het gaat om interverties. De beslissing lets te doen of na te laten hangt immers niet alleen af wan de juistheid van de onderiggende hypothese, mar ook wan andere factoren. in het bijzonder van de walarde die men hecht aan elk van de mogelikk gevolgen van intervenieren of niet-intervenieren.

22. Quintilianus. De opleiding tot redenaar Vertaald, ingeleid en van aantekeningen voorzien daor Piet Gerbrandy Groningen: Historische Litgeverij, 2004. 